начала всего человеческого познавательного и вечно творческой его природы отсутствует понимание человека, а также художественных и культурно-духовных явлений как целостности.

Ключевые слова: дети, детскость, «открытие детства», детский хоровое пение, церковно-певческая практика.

Dolinskaya L. Children's collective singing in the church tradition: ways of interaction of «childishness» and choral singing practice. The article investigates the existence of children's choral singing in the church tradition; The peculiarity of the conditions under which children's choral singing in churches was used and is used; History, conditions and consequences of the interaction of «childishness» with the church action. It is indicated that beyond the understanding of childhood and childishness as the beginning of all human cognitive and eternally creative nature, there is no understanding of man, as well as artistic and cultural-spiritual phenomena as integrity.

Keywords: children, childishness, «opening of childhood», children's choral singing, church-singing practice.

Стаття надійшла до редакції 27.04.2016

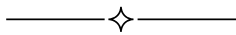

УДК $78.03+781.68$

\title{
Т. Шевченко
}

\section{ДО ПИТАННЯ ВИКОНАВСЬКОЇ ІНТЕРПРЕТАЦІЇ ФОРТЕПІАННОЇ МУЗИКИ М. МЕТНЕРА}

У статті розглянуто особливості виконання фортепіанної музики Метнера на прикладі інтерпретації «Сонати-спогаду» яскравими піаністами XX століття Е. Гілельсом і С. Ріхтером. Автором на основі виконавської партитури ремарок виявлені романтично-емоційний тип виконання Гілельса і незграбно-пластичний, стриманий варіант гри Ріхтера.

Ключові слова: російська фортепіанна соната, фортепіанний стиль Метнера, Соната-спогад, виконавська партитура ремарок.

Долі російської фортепіанної сонати рубежу XIX-XX століть, в тому числі сонат М. Метнера, - одна з мало вивчених на сьогоднішній день тем. 3 різних теоретичних і історичних досліджень, в яких так чи інакше порушується коло проблем зазначеного жанру, ми можемо вказати лише на дві роботи, в яких російська фортепіанна соната розглядається в історичній перспективі. Це - дисертаційні роботи Є. Сорокіної («Деякі проблеми розвитку фортепіанної сонати в Ро- 
ciї», 1976 г.) і Ю. Москалець («Російська фортепіанна соната рубежу XIX-XX століть в атмосфері художніх шукань епохи», 2004 рік).

Якщо в першій роботі досліджуваному жанру присвячений один розділ, то в другій - хронологічні рамки і проблематика історії російської фортепіанної сонати зазначеного періоду розширюються.

Небувалий розквіт на початку XX століття в творчості С. Рахманінова, О. Скрябіна і М. Метнера російської фортепіанної сонати, з різних причин незатребуваної в попередній період, заслуговує, на наш погляд, більш уважного розгляду даного жанру сучасною музичною наукою. Як справедливо вказує Ю. Москалець, «подібних перепадів в долі жанру, привнесеного з європейської музичної традиції, дає можливість глибше зрозуміти характер еволюційних процесів, що протікають в російській культурі і відбилися в сфері музичної творчості, не тільки висунула фортепіанну сонату на один з перших планів в загальній картині музичних жанрів, а й сприяла проникненню сонатного мислення в інші сфери художньої творчості» [2, с. 3].

Все це визначає актуальність нашого дослідження, загальна спрямованість якого пов'язана з новими підходами у вивченні російської фортепіанної сонати на прикладі виконавського прочитання сонати Миколи Карловича Метнера. Крім того, актуальність роботи полягає і в тому, що виявлення своєрідності виконавських підходів ряду піаністів до такого значного твору Метнера як «Соната-спогад» дозволяє розвивати важливу сферу сучасного музикознавства - виконавське музикознавство.

Масштаб творчої діяльності піаніста, композитора і педагога Миколи Метнера ще недостатньо визначено і вивчено. Незважаючи на постійну увагу до його музики з боку видатних піаністів (С. Рахманінов, О. Зілоті, Г. Нейгауз, М. Юдіна, С. Ріхтер, Є. Могилевський, Ю. Понізовкіна, Л. Власенко, Д. Огдон, П. де Грот, Т. Джадд та ін.), деякі великі твори (серед яких фортепіанні сонати) залишаються маловідомими і рідко виконуваними. Специфіка метнеровського стилю, про яку писали І. Зетель, А. Шацкес, Г. Нейгауз і ін., змушує шукати нові підходи в напрямку його виконавського освоєння, які ми досліджуємо, спираються на метод аналізу ремарок О. Сокола.

Аналіз образного змісту «Сонати-спогаду», яку, за словами самого Метнера, він любив більше інших своїх фортепіанних сонат, дозволяють:

по-перше, виявити в авторських вказівках фактори, що допомагають заглибитися в особливості стилю композитора; 
по-друге, на прикладі аналізу фразіровочних, артикуляційних, динамічних, темпових, метро-ритмічних і образних ремарок сонати розкрити взаємодію композиторського задуму і виконавських засобів виразності;

i, по-третє, визначити особливості іiі трактування у виконанні Е. Гілельса і С. Ріхтера.

В нашій роботі вперше запропонований виконавський погляд на зміст фортепіанної сонати Метнера, заснований на порівнянні графічного аналізу нотного тексту і його звукового відтворення. Крім того, нами аналізуються деякі особливості виконання рядом концертуючих піаністів однієї з найпопулярніших фортепіанних сонат Н. Метнера - «Сонати-спогаду».

Метнер - один з тих композиторів, який дбав про точність розуміння його творчих ідей, що тягло за собою досить докладні і об’ємні авторські роз'яснення щодо виконавських аспектів.

У творчому доробку Метнера фортепіанна соната представлена 14 зразками. Як об'єкт аналізу для даної статті нами обрана «Сонатаспогад», яку Метнер, за словами самого композитора, любив більше інших своїх сонат. «Соната-спогад» (ор. 38) і «Трагічна соната» (ор. 39) увійшли в два цикли фортепіанних творів композитора, названі ним «Забутими мотивами».

Музика аналізованої сонати позбавлена зовнішньої помітності або віртуозності і творча думка Г. Нейгауза направляє виконавців на пошук в музичному тексті твору лірико-споглядального настрою і образів, що втілюють занурення в минуле. За його словами, «Соната-reminiscenza» і справді є не тільки розповіддю, але і спогадом про щось давно минуле... Цикл «Забуті мотиви» знову наполегливо повертає до минулого... його музика наповнена почуттям благоговіння і любові до дійсно прекрасного, славного минулого» [3, c. 33].

Написана «Соната-спогад» в період очікуваного Метнером від’їзду з Росії (в Буграх). Ймовірно, що смуток і ніжна поезія цієї музики відповідали тому настрою, в якому композитор перебував, знаходячись далеко від міської суєти, наодинці з собою.

Завдяки спогадам А. Трояновської ми знаємо про перше виконання автором даного твору в домашній затишній обстановці: «Повна наша самотність в лісі, зима за темними вікнами його кімнати і багатство фортепіанної звучності під його руками - все це справляло на нас абсолютно чарівне враження» [5, с. 136]. 
Концентрованість думок і почуттів в музиці Сонати призвела до прагнення автора як можна більш ретельно відбити в нотному тексті свої побажання і рекомендації для виконавців. «Особливе місце інтелектуалізму визначало і своєрідну манеру письма, коли думка настільки концентрована і напружена, що не допускає «байдужих» звуків. В об’єктивності висловлювання, його строгості бачилася М. Метнеру справжня життєстійкість мистецтва»[1, с. 79].

Редакторська сторона творів Метнера надзвичайно докладна і зручна для формування виконавцем своєї інтерпретації. Г. Нейгауз із захопленням пише, що «я насилу назву іншого композитора, який умів би з такою дивовижною точністю і тонкістю зафіксувати в нотному тексті все, що він хоче висловити своєю музикою і бажає від виконавця» [3, с. 34]. Поєднання в одній особі видатного композитора і виконавця знаходить переломлення і в особливій редакторській точності творів Метнера - мало хто з композиторів вищого рангу записували наміри з настільки вражаючою, нерідко скрупульозною точністю. Це було тим більш важливо для композитора, що «непопулярність своїх творів Метнер все більше схильний пояснювати складної манерою письма, яка позбавляє твори необхідної доступності. I для сприйняття, i - не меншою мірою - для розучування i виконання» $[1$, с. 49].

У дослідженні «Виконавські ремарки, образ світу і музичний стиль» О. Сокол говорить про необхідність дослідження ремарок «в аспекті музичного стилю і в рамках змісту художнього образу світу композитора. В такому аспекті ремарки, безсумнівно, є репрезентатором експресивно-мовного стилю музики композитора - 3 одного боку, і установками для іiї виконавської інтерпретації - з іншого, так як містять в собі істотні ознаки інтонаційно-художніх образів» $[4$, c. 36].

В образності ремарок, в їх максимально можливій мірі точності авторського задуму Метнер бачив своєрідний прожектор, він висвітлює виконавцю шлях пошуків. Композитор не боявся їх незвичності - важливіше було знайти найбільш влучну, а то і єдину (з його точки зору) зі словесних характеристик. 3 отриманого списку можна виділити кілька груп термінів, які дадуть виконавцю картину настрою Сонати-спогаду.

Найбільш активно застосовується М. Метнером термін espressivo, який виступає як самостійно, так і в поєднанні з іншими термінами, що вказує на різноманіття образно-поетичних відтінків виразної гри: 
- «невимушено» (Sempre espressivo e disinvolto - початок сонати, перші 16 тактів),

- «споглядально розмірковуючи» (Espressivo meditamente тт. 61-83),

- «дуже співучо» (Molto cantabile ed espressivo - тт. 114-118),

- «підкреслюючи» (Espressivo marcato - тт. 133-137), що вказує на артикуляційну манеру проголошення в партії лівої руки і вимагає від виконавця інтенсивної атаки звуку,

- «спокійно» (Tranquillo ed espressivo - тт. 198-214); наголосимо, що використання даної ремарки застерігає виконавця від захоплення експресією і зайвої насиченістю звуку,

- «трохи весело» (Poco giocoso, ma sempre espressivo - тт. 301308); ремарка вказує на характер гри, який зберігає свою виразність навіть в розчленованій грі при staccato під лігою. Незважаючи на відособленість кожного звуку, вони об'єднані виразністю структури (мотиву),

- «зв'язно» (Sempre espressivo e legato - тт. 340-357); зазначені фрази розташовані у верхньому голосі партії правої руки і ця ремарка передбачає чітке і насичене звучання, подібне до технології видобування звуків на струнному інструменті (скрипці).

Досить активно в нотному тексті сонати застосовуються ремарки Cantabile i характерний для образного ладу Метнера супутній йому термін Semplice (просто), а також Cantando, поруч з яким активно застосовується вказівка Risoluto (рішуче), що відноситься не стільки до зміни загального образного змісту, скільки до зміни всередині вже даної основи, пов'язаної з манерою артикуляції.

Як доповнення до настрою виразного співу на фортепіано, який асоціюється з вокалізованою розповіддю про душевні переживання, сприймається термін Meditamente, що вносить в цю експресію почуттів момент перемикання на споглядальність

Таким чином, аналіз виконавських ремарок вказує на особливе значення в сонаті кантілени, яке вимагає від виконавця глибшого туше і уважного ставлення до втілення різних граней розспіву. До числа незвичайних метнерівських термінів належить «п'єсне туше». Часте згадування в нотатках підкреслює його значимість; 3 «П’єсним туше» Метнер пов'язував шлях до досягнення фортепіанного «співу». У свідомості учнів Метнера воно чітко асоціювалося з грою плоскими пальцями і їх найбільшою близькістю до клавіатури. У поєднанні з пластичністю («побільше п’єсного туше і плас- 
тики») тут відкривалися багатющі можливості звукових нюансів і градацій.

Також звернемо увагу на характерне для романтиків перемикання образного світу сонати з образів легкості, веселощів, танцювальності (Danzando) на елементи вкрадливості і похмурого відчуття (Tenebroso).

Звертає на себе увагу спільний вплив двох ремарок (Svegliando «прокидаючись» i All'improvisa - «несподівано»), які означають «несподіване пробудження» і повинні змінити внутрішній настрій виконавця миттєво.

Ремарка Concentrando («зосереджено»), що з'являється 4 рази на нотному тексті сонати, підкреслює внутрішню зосередженість головного героя, зануреного в роздуми-спогади.

Отже аналіз авторських ремарок «Сонати-спогаду» дозволяє виділити в ній таку драматургію змін модусів настрою як:

- зосередженість;

- експресивний спів;

- пристрасність;

- медитативність.

При вивченні словесних ремарок «Сонати-спогаду» М. Метнера був виявлений прямий зв'язок між ними і семантикою аналізованого музичного твору. Ретельне уточнення композитором своїх художніх намірів вимагає від виконавця уважного прочитання цих вербальних авторських вказівок.

Як писав дослідник творчості Метнера I. Зетель, «Сонату-спогад» грають частіше за інші сонати Метнера. I це зрозуміло - вона вся, починаючи з теми вступу, проспівана. У ній немов акумулювалось прагнення композитора до пісні - першооснови музики» [1, с. 142]. Маловідомі позначки Метнера на полях брошури Ф. Бузоні «Entwurf einer neuen Asthetik des Tonkunst» свідчать: «Чим натхненніше твір, тим точніше воно записується. Чим натхненніше виконання, тим воно ближче до записаного автором. Пушкін про натхнення!»

Зневагу до авторських рад Метнер вважав згубною, але у виконавцях він бачив не копіїстів, а художників, індивідуально заломлюючих авторські бажання. Давні дебати про ставлення до авторських вказівок, а в кінцевому підсумку - про міру творчої самостійності артиста, дано вирішити лише конкретній художній практиці. I тут вкрай важливо знайти об'єктивні критерії оцінки виконавської індивідуаль- 
ності, що і є другим завданням даної статті, яка полягає в з'ясуванні специфіки інтерпретації «Сонати-спогаду» найбільшими піаністами ХХ століття - Е. Гілельсом і С. Ріхтером.

Основним методом, що дозволяє, на наш погляд, розкрити головні пункти відмінностей в інтерпретації сонати, є «Виконавська партитура ремарок», яка представляє собою чотирирядкову партитуру, в якій виписуються:

- над верхньою лінійкою - розмір, темп, характер руху і його зміни;

- під верхньою лінійкою - позначення характеру інтонування (тобто ознаки музичних образів);

- над другою лінійкою - артикуляційні ліги і артикуляції (словесні або графічні) в партії правої руки;

- під другою лінійкою - фразіровочні ліги в партії правої руки;

- над третьою лінійкою - артикуляційні ліги і артикуляції (словесні або графічні) в партії лівої руки;

- під третьою лінійкою - фразіровочні ліги в партії лівої руки;

- над нижньою лінійкою записуються рівні стабільної динаміки і процесуальні динамічні відтінки;

- під нижньою лінійкою - додаткові способи і прийоми виконання (педаль, гліссандо і ін.).

Зіставивши забезпечений автором сонати докладними ремарками текст з виконавськими інтерпретаціями відомих радянських піаністів Е. Гілельса і С. Ріхтера, ми виявили, як випливає зіставлення авторської і виконавської інтерпретації, - очевидно збереження авторської концепції в трактуванні обох піаністів.

Попередньо позначимо головні особливості виконавської манери самого М. Метнера, що відзначаються як сучасниками композитора, так і відчутні при прослуховуванні аудіозаписів виконання ним своїх творів.

Запис сонати у виконанні Еміля Гілельса, який «відкрив» Метнера любителям музики, відноситься до 1968 року. Згідно з нашою виконавською партитурою ми виявляємо романтично-емоційний акцент даного виконавця, що чуємо у великій кількості наростань і спадів звучності, в тому числі і в рамках одного-двох тактів, а також в досить значній мірі мікроприскорень і мікроуповільнень у виконанні Е. Гілельса. Відомий радянський піаніст шкодував, що піаністи дуже слабо знайомі з творчістю цього композитора і рідко виконують його твори. Як інтерпретатор його творів, Гілельс зазначає «російську 
душу» в характері тематики, в тому числі і «Сонати-спогаду». Добре знаючи про багату вокальну творчість М. Метнера, можна припустити, що при виконанні його сонат Гілельс втілював ліричне начало, що йде від пісенної творчості. I про це свідчать слова I. Зетеля: «Дотримання авторської ради ніде не призводить Гілельса до статичності; тон його висловлювання романтично схвильований, часом суворий, але за цією суворістю постійно відчутна гарячність, трепетність, виразне інтонування мовлення» [1].

Святослав Ріхтер вперше зіграв цю сонату в січні і травні 1947 р. у Великому залі Московської консерваторії і в Ленінградській філармонії, а також в грудні 1981 року в Державному музеї образотворчих мистецтв ім. Пушкіна. Про саму сонаті Ріхтер зауважує (в телефільмі про концерт «Грудневі вечори», на якому була виконана «Сонатаспогад»), шо «настрій в ній як в картинах Борисова-Мусатова». Відзначимо своєрідну манеру виконання цієї сонати Ріхтером: з одного боку, незграбно-пластичну стриману і, з іншого боку, вільну; в звукозаписі відчутна сором'язлива і одночасно відкрита подача метнерівських образів.

Цікаві висловлювання сучасників, які чули гру самого Метнера, вони перегукуються і з нашим сприйняттям звукозаписів його виконання. У деяких висловлюваннях про гру Метнера зустрічаються згадки не тільки про підкреслену гостроту, а й про жорсткість, навіть незграбність ритму. Але при цьому ремарки про співучість часті у Метнера: він любив повнокровно проспівати мелодійну канву, як і багато епізодів, розвиваючі тематичні зерна.

Соковитим звучанням, мелодично тонким нюансюванням кожного пасажу відзначені багато записів М. Метнера. Г. Нейгауз бачив особливості метнерівського почерку і в графічній пластичності гри, позбавленої імпресіоністичних туманів. Особливу виразність виконанню Метнера надавало володіння мистецтвом живого висловлювання, завжди внутрішньо виправданого і правдивого. Кожна інтонація була договорена ним до кінця. Гра Метнера викликала у відповідь ток слухацьких симпатій величезною внутрішньою силою, філософської значущістю і піднесеністю.

Запропонована в даному дослідженні «Виконавська партитура ремарок» «зримо» відображає виконавські завдання, спрямовані на фразіровку, з якою пов'язані динамічні, артикуляційні, темпо-ритмічні, педальні вказівки композитора. Розуміння піаністом фразової логіки конкретного музичного тексту, в якому зв'язність і розділь- 
ність подібні до людської мови з ії живим диханням, допомагає простежити за розвитком і стосунками різних музичних образів.

Одним з висновків дослідження є те, що в пошуку необхідних для стилю Метнера виконавських засобів виразності увага піаніста повинна бути спрямована на вивчення піаністичних принципів композитора. Теоретичні положення і авторські поради допоможуть визначити вибір потрібних способів музичної вимови і технологічних прийомів для кожного зафіксованого в нотному тексті образу.

Таким чином, в результаті дослідження пропонується в ході роботи над інтерпретацією фортепіанних сонат Метнера підходити до їх художніх задумів з різних сторін. Один варіант підходу - це створення власного уявлення про образний зміст твору на основі програмної ідеї автора і словесних ремарок в нотному тексті. Інший варіант - на основі глибокого аналізу всіх компонентів нотного тексту правильно його «прочитати», щоб відтворити в звучанні у всій його образноемоційній своєрідності.

Величезний інтерес до фортепіанної сонатної творчості М. Метнера з боку багатьох відомих піаністів підкреслює той потенціал, який містять метнерівські твори. Він змушує направляти увагу сучасних музикантів на можливість розширення своїх репертуарних уподобань шляхом включення в програми фортепіанних сонат Метнера.

Сьогодні виконавець, який прагне до нових репертуарних відкриттів, може виявляти образний зміст фортепіанних сонат Метнера на основі аналітичного зіставлення виразних засобів композиторського тексту з колом засобів, що входять в музично-виконавську поетику.

Творчо-практична успішність вирішення даного компаративного завдання сприятиме подальшому розвитку теоретичного напрямку дослідження фортепіанної спадщини М. Метнера.

\section{СПИСОК ЛІТЕРАТУРИ}

1. Зетель И. Н. К. Метнер - пианист. Творчество, исполнительство, педагогика / И. Зетель. - М. : Музыка, 1981. - 231 с.

2. Москалец Ю. В. Русская фортепианная соната рубежа XIX-XX вв. в атмосфере художественных исканий эпохи. - Автореф. дис. ... канд. искусств / Ю. В. Москалец. - М., 2004. - 26 с.

3. Нейгауз Г. Современник Скрябина і Рахманинова / Г. Г. Нейгауз // Н. К. Метнер. Воспоминания. Статьи. Материалы. - М. : Сов. композитор, 1981. - C. 31-35.

4. Сокол А. Виконавські ремарки, образ світу і музичний стиль / А. В. Сокол. - Одеса : Моряк, 2007. - 276 с. 
5. Трояновская А. Жизнь Н. К. Метнера в Буграх / А. И. Трояновская // Н. К. Метнер. Воспоминания. Статьи. Материалы. - М. : Сов. композитор, 1981. - C. 134-141.

Шевченко Т. К вопросу об исполнтельской интерпретации фортепианной музыки Н. Метнера. В статье рассмотрены особенности исполнения фортепианной музыки Метнера на примере интерпретации «Сонаты-воспоминания» яркими пианистами XX века Э. Гилельсом и С. Рихтером. Автором на основе исполнительской партитуры ремарок выявлены романтически-эмоциональный тип исполнения Гилельса и угловато-пластичный, сдержанный вариант игры Рихтера.

Ключевые слова: русская фортепианная соната, фортепианный стиль Метнера, Соната-воспоминание, исполнительская партитура ремарок.

Shevchenko T. Until supply performing piano music $N$. Medtner. The article describes the features of the execution of piano music by the example of the interpretation of Medtner's «Sonata-memories» brilliant pianists of the twentieth century, Gilels and Richter. The author on the basis of performing scores remarks revealed romantic and emotional type of performance Gilels and angular-plastic, low-key version of the game Richter.

Keywords: Russian Piano Sonata, Piano Style Medtner Sonata recollection performing score remarks.

Стаття надійшла до редакції 20.04.2016

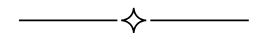

